\title{
Identification of a New Phytophthora Species Causing Root and Runner Rot of Cranberry in New Jersey
}

\author{
James J. Polashock, Jennifer Vaiciunas, and Peter V. Oudemans
}

First author: U.S. Department of Agriculture-Agricultural Research Service, Fruit Laboratory; and second and third authors: Rutgers University, Blueberry and Cranberry Research and Extension Center, 125A Lake Oswego Rd., Chatsworth, NJ 08019. Accepted for publication 1 July 2005.

\section{ABSTRACT}

Polashock, J. J., Vaiciunas, J., and Oudemans, P. V. 2005. Identification of a new Phytophthora species causing root and runner rot of cranberry in New Jersey. Phytopathology 95:1237-1243.

In New Jersey, Phytophthora cinnamomi is the pathogen most commonly isolated from diseased roots and runners of the cultivated cranberry (Vaccinium macrocarpon). A second distinct species of Phytophthora has been isolated from dying cranberry plants and surface irrigation water. This species is homothallic with paragynous antheridia and ellipsoid-limoniform, nonpapillate sporangia. It was tentatively identified as $P$. megasperma in an earlier report. Laboratory experiments demonstrate that the cardinal temperatures for vegetative growth are between 5 and $30^{\circ} \mathrm{C}$ with an optimum near $25^{\circ} \mathrm{C}$. Sporangia are produced at tem- peratures between 10 and $20^{\circ} \mathrm{C}$ with the majority of sporangia produced at 10 and $15^{\circ} \mathrm{C}$. In pathogenicity tests, no growth effect was observed on cranberry plants (cv. Early Black) when tests were conducted at $25^{\circ} \mathrm{C}$; however, significant reductions in plant growth occurred when tests were conducted at $15^{\circ} \mathrm{C}$. This species was insensitive to metalaxyl but was sensitive to buffered phosphorous acid. Sequence analysis of the internal transcribed spacer 1 (ITS1), 5.8S rDNA, and ITS2 regions place these isolates in Phytophthora clade 6 with greatest similarity to Phytophthora taxon raspberry. To our knowledge, this is the first report of isolates of this affiliation in North America. However, the observation of low temperature preferences makes this species unique in an otherwise high temperature clade. The isolates described in this study are tentatively classified as Phytophthora taxon cranberry.
Cranberries (Vaccinium macrocarpon Ait.) are grown in both upland and wetland sites. Irrigation water for both production systems is drawn largely from surface water systems such as streams, lakes, and reservoirs. Therefore, cranberries are exposed to many aquatic organisms that occur in these waterways. The most problematic of these are species in the genus Phytophthora $(4,10,19,20,24)$. Phytophthora root and runner rot can be a major problem especially when cranberry beds are poorly drained and plants are subjected to long periods of saturated soil (20). The primary species found in New Jersey is $P$. cinnamomi, although another species, tentatively identified as $P$. megasperma, has been reported (24). However, $P$. megasperma is a polyphyletic species complex composed of morphologically diverse isolates and highly variable pathogenic characteristics $(2,8,14,16)$. This species has been revised numerous times and it has been shown using DNA sequence data that the classic morphological characteristics used to discriminate taxa in this genus (i.e., sporangial morphology and antheridial form) are highly polymorphic within this group $(8,14)$. Classification of the cranberry isolates was based on morphology (11) and isozyme analysis $(25,26)$; however, accurate classification requires molecular sequence data and analysis with existing data sets $(2,8,15)$.

Typically, cranberry plants infected by $P$. cinnamomi occur in areas with extensive dieback and are often replaced by weedy grass species (20). Growers treat areas infested with $P$. cinnamomi by improving drainage with under-drains or surface ditches and apply a fungicide such as metalaxyl following replanting of the affected area (20). Beginning in 1994, several commercial cran-

Corresponding author: P. V. Oudemans; E-mail address: oudemans@ aesop.rutgers.edu

DOI: $10.1094 /$ PHYTO-95-1237

This article is in the public domain and not copyrightable. It may be freely reprinted with customary crediting of the source. The American Phytopathological Society, 2005. berry beds in Burlington County, New Jersey, were observed with symptoms atypical of root and runner rot. The healthy cranberry plants were growing in small patches and the typical uniform canopy did not develop. Vine dieback was observed but appeared to be randomly distributed. Symptoms on individual runners and uprights appeared, superficially, to be upright dieback (Phomopsis vaccinii). However, the vines were dying from the base of the plant upward and the roots systems were reduced in volume. Isolation from the root and runner tissues of these plants yielded a Phytophthora species distinct from $P$. cinnamomi. Commercial growers on whose farms where this disease occurred observed that continued use of metalaxyl was not effective and the cranberry vines continued to decline.

Other than $P$. cinnamomi, little research has been conducted to characterize species infecting cranberry in terms of pathogenicity, fungicide sensitivity, or temperature relations. Oudemans (24) reported that levels of $P$. cinnamomi baited from surface irrigation water were positively correlated with water temperatures during the early part of the growing season. However, in the same study, the recovery rate of isolates resembling $P$. megasperma was negatively correlated with water temperature. The objectives of the research described herein were to test and compare pathogenicity, fungicide sensitivity, and temperature sensitivity of the two Phytophthora species found in New Jersey. Also, considering the taxonomic complexity of the P. megasperma complex, we further examined the identity of these species using both morphological markers and rDNA internal transcribed spacer (ITS) sequence data for comparison with existing data sets.

\section{MATERIALS AND METHODS}

Fungal isolates. Both P. cinnamomi and the Phytophthora spp. isolates were obtained either from diseased plant tissues or irrigation water by lupine baiting (24). Briefly, isolations from diseased tissues involved washing the roots and runners in cold running 
water. Tissues were cut into $\approx 1-\mathrm{cm}$ segments and pressed into PARPH (10 mg of pimaricin, $100 \mathrm{mg}$ of ampicillin, $10 \mathrm{mg}$ of rifampicin, $50 \mathrm{mg}$ of PCNB, $50 \mathrm{mg}$ of hymexazol, $15 \mathrm{~g}$ of Difco corn meal agar, and distilled water to 1 liter), a Phytophthoraselective medium $(21,32)$. For baiting, 10- to 12-day-old lupine seedlings were floated in reservoirs for 2 days (24). The roots were then excised and plated onto PARPH selective medium. For both isolation methods, the Phytophthora positive samples had visible growth within 2 to 4 days. Subcultures were initially made on PARP medium (antibiotics as above in PARPH, but without hymexazol) and then subcultured on clarified V8-juice agar (22). Initial morphological observations and identification were made from cultures grown on clarified V8-juice agar. Initially, mycelial morphology (coralloid is considered diagnostic for $P$. cinnamomi) and oospore production were used to classify isolates. More detailed morphological observations were made on sporangia using methods optimized for their production and are described below. All isolates (Table 1) were stored at $4^{\circ} \mathrm{C}$ on clarified V8-juice agar slants after an initial growth period at $25^{\circ} \mathrm{C}$ for 7 to 10 days.

Pathogenicity. Pathogenicity of the two Phytophthora species was assessed at two temperatures, 10 and $25^{\circ} \mathrm{C}$. Inoculum was prepared by growing each isolate in a 1-liter flask containing $500 \mathrm{ml}$ of a vermiculite-V8-juice mixture $(500 \mathrm{ml}$ and $40 \mathrm{ml})$ as described by Mircetich and Matheron (23). Six isolates of each species were grown for approximately 4 weeks. At the end of this period, the contents of each flask were measured and equal volumes of each isolate for a given species were combined in a plastic bucket. The vermiculite medium was mixed by hand and then rinsed with water to remove excess V8 juice. An uninoculated control was prepared using only the vermiculite-V8-juice medium. Cranberry cuttings (cv. Early Black or Stevens) were taken from plant material that had been harvested in the fall and stored at 4 to $8^{\circ} \mathrm{C}$ for 3 to 5 months. This material had received adequate chilling (minimum of $1,600 \mathrm{~h}$ at 4 to $7^{\circ} \mathrm{C}$ ) and therefore began growing soon after planting. For all experiments, runners were cut from the stored plant material into 8 to $13 \mathrm{~cm}$ lengths, wrapped in moist paper towels, and placed in refrigerated storage until used (2 to 4 weeks). Phytophthora inoculum was combined with cranberry potting mix (sand/peat, $1: 1$, vol/vol) to achieve a final mixture of 1 to $10 \%$ inoculum (vol/vol). Assays were conducted in $10-\mathrm{cm}$ square plastic pots each with 10 unrooted cranberry cuttings planted vertically approximately $8 \mathrm{~cm}$ deep. The pots were watered daily to maintain constant high soil moisture; however, pots were not flooded. Four replications were used for each treatment, and the number of shoots, total shoot length, and the number of surviving plants were assessed after 6 weeks. Assays were run four times at two temperatures $\left(15\right.$ and $\left.25^{\circ} \mathrm{C}\right)$, and assays at different temperatures were analyzed as separate experiments to test if growth in infested medium at a given temperature was significantly different from the control. Each pot was

TABLE 1. Isolates of Phytophthora species used in this study

\begin{tabular}{|c|c|c|c|}
\hline Number & Species & $\begin{array}{l}\text { Origin (Burling- } \\
\text { ton County, NJ) }\end{array}$ & Source \\
\hline P1067 & $P$. taxon cranberry & Browns Mills & Lupine bait \\
\hline P1070 & $P$. taxon cranberry & Browns Mills & Vaccinium macrocarpon \\
\hline P1073 & $P$. taxon cranberry & Browns Mills & Lupine bait \\
\hline P1074 & $P$. taxon cranberry & Browns Mills & Lupine bait \\
\hline P1074A & $P$. taxon cranberry & Browns Mills & V. macrocarpon \\
\hline P1081 & $P$. taxon cranberry & Browns Mills & Lupine bait \\
\hline P1089 & $P$. taxon cranberry & Indian Mills & V. macrocarpon \\
\hline P1410 & $P$. taxon cranberry & Indian Mills & Lupine bait \\
\hline P1001 & P. cinnamomi & New Gretna & V. macrocarpon \\
\hline P1002 & P. cinnamomi & Chatsworth & V. macrocarpon \\
\hline P1085 & P. cinnamomi & Browns Mills & Lupine bait \\
\hline P1091 & P. cinnamomi & Indian Mills & Lupine bait \\
\hline P1233 & P. cinnamomi & Chatsworth & Lupine bait \\
\hline P1201 & P. cinnamomi & Jenkins & Lupine bait \\
\hline
\end{tabular}

used as an experimental unit, and the survival and growth parameters were averaged for the 10 cuttings in each pot. A StudentNewman-Kuels mean separation test $(P=0.05)$ was used to compare growth of cranberry vines inoculated with either Phytophthora species versus a noninoculated control.

Effect of temperature on spore production and mycelial growth. Sporangium production $(5,29)$ was assessed at three temperatures $\left(10,15\right.$, and $\left.20^{\circ} \mathrm{C}\right)$. Sporangia were produced by growing isolates in $1 \%$ V8-juice broth (22) for $24 \mathrm{~h}$ in 9-cm-diameter petri dishes. The broth was removed using a Pasteur pipette connected to a vacuum. Stream water (collected near a cultivated cranberry field) was added after rinsing the mycelium twice. The petri dishes were placed in incubators in the dark at the appropriate temperatures. Sporangium production was assessed by counting the total number of sporangia present in each petri dish at each sampling time (5). The experiment was conducted for 17 days and plates were examined every 3 days. At the end of the experiment, the total number of sporangia produced by a single isolate was determined as the sum of the sporangia recorded on each of the five sampling times. This method may over estimate sporangium production since some sporangia may have been counted twice; however, for the most part, sporangia released zoospores within 3 days of being produced and empty sporangia were not counted. The total numbers of sporangia were determined as the sum of all sporangia for each isolate across the three temperatures. Relative sporangial production was determined as the sporangia production at a specific temperature divided by the total sporangia produced for that isolate. These values were calculated for each isolate across all three temperatures, and an average and standard deviation for the isolates of each species were calculated.

Mycelial growth was assessed at seven temperatures at $5^{\circ} \mathrm{C}$ increments from 5 to $35^{\circ} \mathrm{C}$. Assays were conducted on V8-juice agar as described previously (24). Each isolate was grown on V8juice agar for 3 to 5 days. A 5-mm plug was taken from the edge of the colony and placed mycelium-side down on fresh V8-juice agar. All plates were incubated for $24 \mathrm{~h}$ at $20^{\circ} \mathrm{C}$ and transferred to appropriate temperatures. After $48 \mathrm{~h}$, the edges of the colonies were marked. The colony edges were marked every 48 to $96 \mathrm{~h}$ thereafter and until at least two incremental growth marks were made. The growth rates were determined as millimeters per hour.

It was observed that oospores often became granulated in appearance and this seemed to be related to temperature. To examine this further, oospore production was evaluated at two temperatures. Cultures were grown on clarified V8-juice agar at 15 and $25^{\circ} \mathrm{C}$, and plates were evaluated after 12 to 18 days. Three plates were grown with each of two species isolates for each replication of the experiment and the experiment was conducted three times.

Fungicide bioassays. To conduct fungicide bioassays, an amended agar technique was employed $(6,7)$. Two fungicides were used in this study, metalaxyl and buffered phosphorous acid. In both cases, half-strength corn meal agar (Difco Laboratories, Detroit, MI) containing increasing fungicide concentrations was used to conduct the bioassays. For metalaxyl (technical grade $97 \%$, Ciba Geigy Corp., Basle, Switzerland), five concentrations were used $(0.05,0.25,0.5,2.5$, and $5 \mu \mathrm{g} / \mathrm{ml}$ of medium). The fungicide was dissolved in acetone and added to the medium with a final concentration of $1 \mu \mathrm{l}$ of acetone per $1 \mathrm{ml}$ of medium. A control was prepared with the same level of acetone but with no fungicide added. For phosphorous acid, a stock solution was prepared in 0.5 M MES buffer (2-[N-morpholino]ethane-sulfonic acid) adjusted to $\mathrm{pH}$ 6.2. Subsequent dilutions of the fungicide were also made in $0.5 \mathrm{M}$ MES, $\mathrm{pH} 6.2$, and a final concentration in the growth medium was $1.0 \mathrm{mM}$. All solutions were filter sterilized and added after the medium was autoclaved. For phosphorous acid, four concentrations were used $(2.5,12.5,62.5$, and $125.0 \mu \mathrm{g} / \mathrm{ml}$ of medium). A nonfungicide-amended control was prepared by adding $0.5 \mathrm{M} \mathrm{MES,} \mathrm{pH} \mathrm{6.2,} \mathrm{buffer} \mathrm{only.}$ 
To conduct the bioassays, isolates were grown on nonamended corn meal agar for 3 to 5 days. One $5-\mathrm{mm}$ plug cut from the growing edge of the colony was placed mycelial-side down in the center of each plate. The colonies were incubated at $20^{\circ} \mathrm{C}$, and the colony margins were marked at 3 and 6 days to measure the distance grown over the 3-day period. Two measurements were made per plate and four replicates were used for each experiment. The dosage-responses were quantified using a probit transformation of the percent growth inhibition plotted against the log of the fungicide concentration. A simple linear regression line was fitted to the data and a $50 \%$ effective concentration $\left(\mathrm{EC}_{50}\right)$ value was estimated.

DNA isolation. Cultures were grown in $50 \mathrm{ml}$ of liquid clarified V8-juice medium at $25^{\circ} \mathrm{C}$ for 15 days. Mycelium was harvested and excess medium was removed by suction filtration through Miracloth (Calbiochem, EMD Biosciences, San Diego, CA). Approximately $150 \mathrm{mg}$ of mycelium was then suspended in $10 \mathrm{ml}$ of CTAB buffer (30). The suspension was frozen at $-20^{\circ} \mathrm{C}$ for at least $30 \mathrm{~min}$ followed by heating at $65^{\circ} \mathrm{C}$ for $30 \mathrm{~min}$. The suspension was extracted with an equal volume of chloroform and centrifuged at $8,000 \times g$ for $10 \mathrm{~min}$. The chloroform extraction was repeated and the nucleic acid was precipitated from the supernatant by adding 0.7 volumes of isopropanol to each tube followed by centrifugation at $10,000 \times g$ for $10 \mathrm{~min}$. Pellets were resuspended overnight at $4^{\circ} \mathrm{C}$ in $1 \mathrm{ml}$ of Tris-EDTA (TE) buffer. RNase A $(2 \mu \mathrm{l}$ of $0.25 \mu \mathrm{g} / \mu \mathrm{l})$ was added to the resuspended nucleic acid and tubes were incubated at $37^{\circ} \mathrm{C}$ for $30 \mathrm{~min}$. The solution was extracted one more time with an equal volume of chloroform and the DNA was precipitated with a $1 / 10$ volume

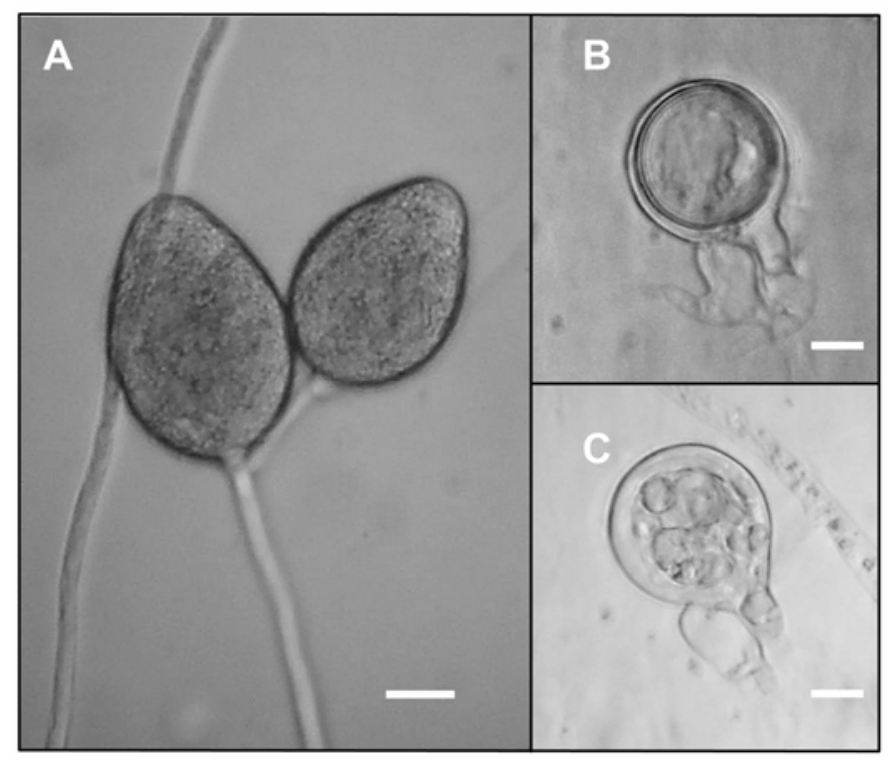

Fig. 1. Morphology of Phytophthora taxon cranberry isolates described in this report: A, sporangia; $\mathbf{B}$, healthy oospore; and $\mathbf{C}$, an aborted oospore. The bar represents a $10-\mu \mathrm{m}$ increment. of $3 \mathrm{M} \mathrm{NaOAc}$ and $2 \mathrm{vol}$ ETOH. Pellets were resuspended in $25 \mu \mathrm{l}$ of TE.

ITS amplification and sequence analysis. DNA containing the complete ITS1, 5.8 ribosomal RNA gene, and ITS2 was amplified by polymerase chain reaction (PCR) using universal ITS primers 1 and 4 (33) for all isolates listed in Table 1. Amplification reactions contained $1 \times$ PCR buffer A (Fisher Scientific, Pittsburgh, PA), $0.2 \mathrm{mM}$ dNTPs, 2.5 units of Taq polymerase (Fisher Scientific), $0.2 \mu \mathrm{M}$ of each primer, and approximately $5 \mathrm{ng}$ of template DNA in a final volume of $20 \mu \mathrm{l}$. All PCRs consisted of one cycle of $94^{\circ} \mathrm{C}$ for $3 \mathrm{~min} ; 30$ cycles of $94^{\circ} \mathrm{C}$ for $30 \mathrm{~s}$, $57^{\circ} \mathrm{C}$ for $30 \mathrm{~s}, 72^{\circ} \mathrm{C}$ for $1 \mathrm{~min}$; and a final cycle of $72^{\circ} \mathrm{C}$ for $5 \mathrm{~min}$. Amplified fragments were separated by agarose electrophoresis and purified using spin columns (MoBio Labs, Solana Beach, CA). Purified fragments were ligated into the pGemT vector (Promega Corp., Madison, WI) according to the manufacturer's directions and transformed into Escherichia coli strain $\mathrm{DH} 5 \alpha$. Isolates containing plasmids with proper size inserts were grown overnight in Luria-Bertani (LB) medium containing ampicillin $(80 \mu \mathrm{g} / \mathrm{ml})$, and plasmids were isolated using spin columns (Mo Bio Laboratories, Solana Beach, CA). Sequencing was performed using plasmids representing all isolates listed in Table 1. Reactions were prepared using the DCTS Quick Start kit (Beckman Coulter, Fullerton, CA) and run on a CEQ 8000 (Beckman Coulter). Sequence analysis was performed using various modules in the Lasergene software package (DNAStar Inc., Madison, WI). Similarity to published sequences was determined using BLAST (1). Sequences for phylogenetic comparison were downloaded from GenBank. Alignments were performed using Clustal $\mathrm{W}$ in the Lasergene software package. Alignments were manually adjusted in Microsoft Word (Microsoft Corp., Redmond, WA). Gaps were removed from the data set and then reintroduced into the data set as coded characters. Neighbor joining analyses were performed using PAUP* $4.0 \mathrm{~b} 10$ (31). Support for each clade was assessed by bootstrap analysis in PAUP* using 1,000 replicates. The tree was drawn using TreeView (27).

\section{RESULTS}

Morphology. Isolates identified as $P$. cinnamomi exhibited all of the morphological traits attributed to that species (11). The isolates tentatively identified as $P$. megasperma are hereafter referred to as Phytophthora taxon cranberry. Sporangia were nonpapillate, ellipsoid-limoniform in shape and measured $40.1 \pm$ $4.4 \mu \mathrm{m}$ by $30.1 \pm 3.5 \mu \mathrm{m}$ with a length/breadth ratio of $1.341 \pm$ 0.12 (Fig. 1A). The isolates were homothallic with oogonia ranging from 21 to $27 \mu \mathrm{m}$. Oospores were plerotic (17 to $23 \mu \mathrm{m}$ ) and displayed antheridia with paragynous attachment (Fig. 1B). Oospores became increasingly granulated when colonies were grown above $15^{\circ} \mathrm{C}$ (Fig. 1C) with approximately $80 \%$ abortion in isolates grown at $25^{\circ} \mathrm{C}$.

Pathogenicity. Cranberry cuttings grown in noninfested soil grew significantly more than cuttings grown in Phytophthorainfested soil based on four parameters measured (Table 2). Growing plants at $25^{\circ} \mathrm{C}$ as opposed to $15^{\circ} \mathrm{C}$ generally caused a marked

TABLE 2. Pathogenicity of two Phytophthora species on cranberry (cv. Early Black) cuttings at different temperatures

\begin{tabular}{|c|c|c|c|c|c|c|c|c|}
\hline \multirow[b]{2}{*}{ Treatment } & \multicolumn{2}{|c|}{ Survival $(\%)^{\mathrm{v}}$} & \multicolumn{2}{|c|}{ Average shoot length $(\mathrm{cm})^{\mathrm{w}}$} & \multicolumn{2}{|c|}{ Total growth $(\mathrm{cm})^{\mathrm{x}}$} & \multicolumn{2}{|c|}{ Average no. of shoots/plan } \\
\hline & $15^{\circ} \mathrm{C}^{\mathrm{y}}$ & $25^{\circ} \mathrm{C}$ & $15^{\circ} \mathrm{C}$ & $25^{\circ} \mathrm{C}$ & $15^{\circ} \mathrm{C}$ & $25^{\circ} \mathrm{C}$ & $15^{\circ} \mathrm{C}$ & $25^{\circ} \mathrm{C}$ \\
\hline Control & $76.9 \mathrm{a}^{\mathrm{z}}$ & $90.0 \mathrm{a}$ & $10.3 \mathrm{a}$ & $24.7 \mathrm{~b}$ & $123.8 \mathrm{a}$ & $428.4 \mathrm{a}$ & 1.5 & $2.0 \mathrm{a}$ \\
\hline P. cinnamomi & $56.4 \mathrm{~b}$ & $92.5 \mathrm{a}$ & $3.3 \mathrm{~b}$ & $9.6 \mathrm{c}$ & $23.8 \mathrm{~b}$ & $111.9 \mathrm{~b}$ & 1.3 & $1.3 \mathrm{~b}$ \\
\hline Phytophthora taxon cranberry & $53.9 \mathrm{~b}$ & $82.5 \mathrm{a}$ & $6.7 \mathrm{~b}$ & $31.0 \mathrm{a}$ & $58.1 \mathrm{~b}$ & $461.8 \mathrm{a}$ & 1.5 & $1.9 \mathrm{ab}$ \\
\hline
\end{tabular}

${ }^{v}$ Survival refers to the percentage of surviving cuttings out of 10 planted per pot.

${ }^{\text {w }}$ Average shoot length is the average length of each living shoot.

${ }^{x}$ Total growth is the length of all shoots in a pot.

y Temperature at which the study was conducted. Temperatures were run as separate experiments and analyses were likewise run separately.

${ }^{\mathrm{z}}$ Means within a column followed by the same letter are not statistically different (Student-Newman-Kuels mean separation test, $P=0.05$ ). 
increase in plant growth and survival. $P$. cinnamomi caused growth reductions in average shoot length and total growth per pot at both temperatures. There was also a reduction in the average number of shoots per plant at $25^{\circ} \mathrm{C}$ but not at $15^{\circ} \mathrm{C}$. The number of surviving cuttings was reduced at $15^{\circ} \mathrm{C}$ but not at $25^{\circ} \mathrm{C}$. Phytophthora taxon cranberry reduced survivorship, average shoot length, and total growth per pot at $15^{\circ} \mathrm{C}$ but not at $25^{\circ} \mathrm{C}$ (Table 2). Root and stem weights were taken; however, due to the difficulty in removing roots from stems and the variability in stem weight, it was not possible to quantify root reduction due to infection.

Sporangium production and mycelial growth. Sporangium production was monitored over a 17-day period at three incubation temperatures $\left(10,15\right.$, and $\left.20^{\circ} \mathrm{C}\right)$. P. cinnamomi produced greater quantities of sporangia than did the Phytophthora taxon cranberry isolates (data not shown). These species displayed distinct temperature optima for sporangium production (Fig. 2). The temperature effects on sporangium production were consistent for all isolates within each species tested for all experiments. Within the temperature ranges tested, sporangium production was positively correlated with increasing temperature for $P$. cinnamomi and negatively correlated for Phytophthora taxon cranberry.

Temperature optima were similar for both species $\left(25^{\circ} \mathrm{C}\right)$ and neither species could grow at $35^{\circ} \mathrm{C}$ (Fig. 3). However, Phytophthora taxon cranberry did grow slightly at $5^{\circ} \mathrm{C}$, whereas $P$. cinnamomi did not. Both species resumed faster growth rates when taken from 5 to $20^{\circ} \mathrm{C}$; however, isolates held at $35^{\circ} \mathrm{C}$ for 7 days did not resume growth at lower temperatures and were presumably dead.

Fungicide bioassays. Two oomycete-specific fungicides were tested to assess sensitivity and compare $\mathrm{EC}_{50}$ values between $P$. cinnamomi and the Phytophthora taxon cranberry isolates. The dosage response lines for each species were similar over two experiments (Fig. 4). For P. cinnamomi, an average $\mathrm{EC}_{50}$ of $0.081 \pm$ $0.04 \mu \mathrm{g} / \mathrm{ml}$ was estimated for metalaxyl. For Phytophthora taxon cranberry, the $\mathrm{EC}_{50}$ values were beyond the range used in the test for this fungicide. Estimates placed the $\mathrm{EC}_{50}$ beyond $100 \mu \mathrm{g} / \mathrm{ml}$ for this species. For P. cinnamomi, an average $\mathrm{EC}_{50}$ of $24.4 \pm$ $12.1 \mu \mathrm{g} / \mathrm{ml}$ was estimated for buffered phosphorous acid. For Phytophthora taxon cranberry, an average $\mathrm{EC}_{50}$ of $69.51 \pm$ $2.9 \mu \mathrm{g} / \mathrm{ml}$ was estimated.

Sequence analysis. All P. cinnamomi isolates used in this study had identical ITS region sequences (i.e., isolates P1001, 1002, $1085,1091,1233$, and 1210) and a representative sequence was deposited in GenBank (AY964101). Similarly, all Phytophthora taxon cranberry isolates used in this study had identical ITS

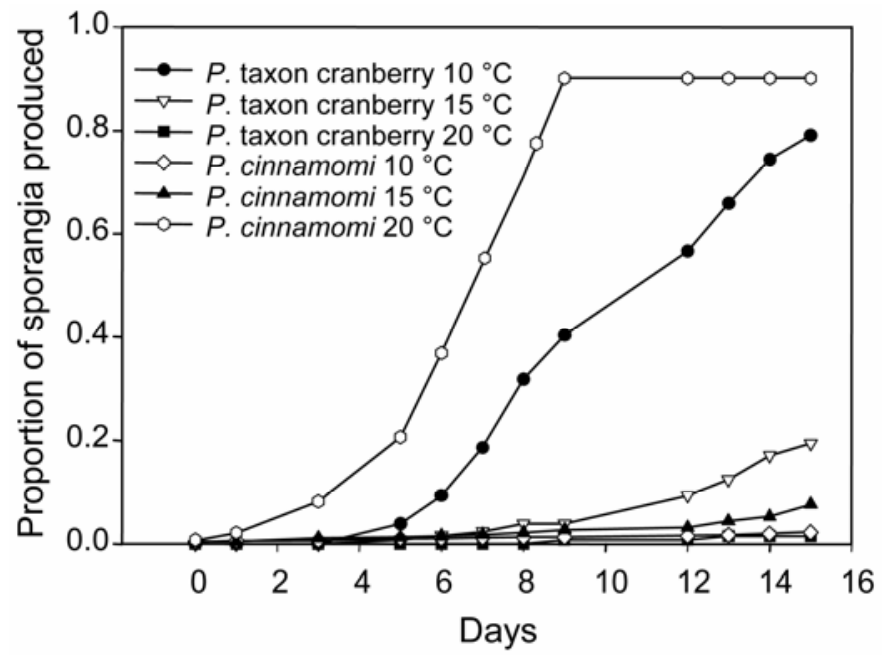

Fig. 2. Effect of temperature on sporangium production in two Phytophthora species: Phytophthora taxon cranberry $(n=8)$; and P. cinnamomi $(n=6)$. region sequences (i.e. isolates P1067, 1070, 1073, 1074, 1074A, 1081,1089 , and 1088) and a representative sequence was deposited in GenBank (AY964102). BLAST searches and sequence alignments with other Phytophthora species downloaded from GenBank confirmed the $P$. cinnamomi species identification (Fig. 5). The Phytophthora taxon cranberry sequences, although similar to other Phytophthora species, did not match any in the database (data not shown). Alignments with ITS regions of representative Phytophthora species showed that Phytophthora taxon cranberry was most closely related to members of ITS clade 6 (Fig. 5) and more specifically, to the Phytophthora taxon raspberry $(2,8)$. When Phytophthora taxon cranberry was compared with only Phytophthora taxon raspberry (AF541905, AF541903, and AF541904), percent identity was about $98 \%$.

\section{DISCUSSION}

P. megasperma is a polyphyletic, morphologically diverse species. Several researchers have identified distinct morphological and molecular subgroups within $P$. megasperma sensu lato $(8,11,14,16)$ and many of these probably represent distinct species. The homothallic, nonpapillate isolates described previously from cranberry (24) as $P$. megasperma-like are classified in this study as a potentially new species within clade 6 defined by Cooke et al. (8). Based on sequence analysis of the ITS1, 5.8S rDNA, and ITS2 regions, these isolates appear to be most closely related to Phytophthora taxon raspberry as described by Brasier et al. (2). The isolates within Phytophthora taxon raspberry are represented by only a few isolates from geographically distinct locations $(2,16)$, and the cranberry isolates are the first in this group to be described from North America. Although the isolates described here have smaller oospores than is generally accepted for $P$. megasperma $(9,11)$, the characteristics of Phytophthora taxon raspberry share some of the characteristics of the cranberry isolates. For example, both are homothallic and nonpapillate with approximately similar morphometrics and similar colony morphologies (data not shown). Brasier et al. (2) describe members of this clade as high temperature isolates based on mycelial growth. The cranberry isolates were killed at $35^{\circ} \mathrm{C}$, whereas the Phytophthora taxon raspberry isolates were reported to grow at 33 to $35^{\circ} \mathrm{C}$. In fact, the temperature response for sporangium production, oospore abortion, pathogenicity, and isolation frequency (24) indicates that the cranberry isolates have a low temperature preference.

Recent species descriptions for the genus Phytophthora such as $P$. nemarosa (17) have been based on morphometric analyses, DNA sequence analysis, and pathogenicity. However, the clade 6

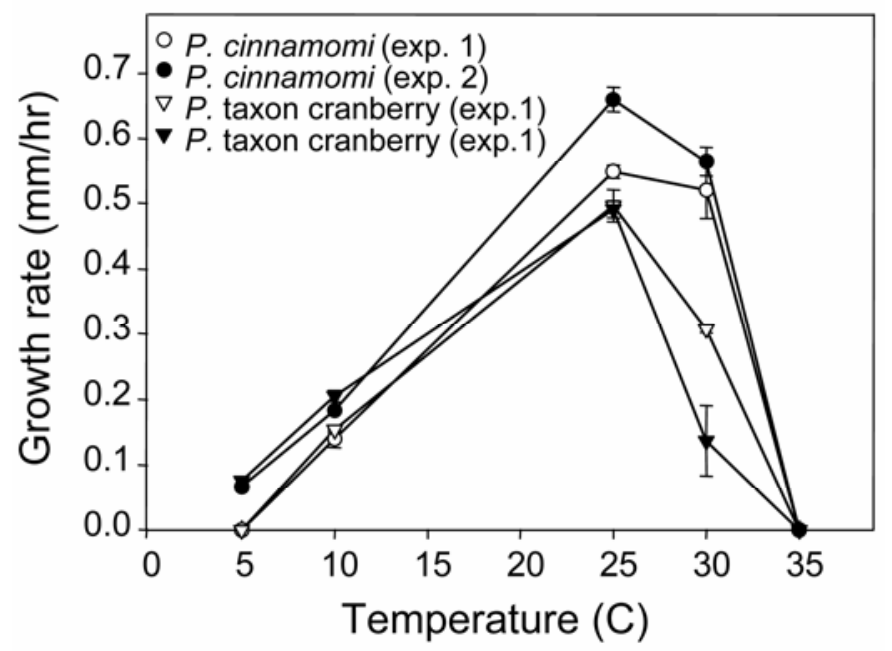

Fig. 3. Effect of temperature on mycelial growth of two Phytophthora species: P. cinnamomi $(n=6)$; and Phytophthora taxon cranberry $(n=8)$. 
group $(2,8,15)$ should be investigated more thoroughly before making species designations. Based on the dynamic status of this group, we will refer to the isolates as Phytophthora taxon cranberry pending continued investigation. This conforms to the tentative nomenclature previously used (2), and as more isolates from this group are discovered, a taxonomic description should be made.

Pathogenicity assays demonstrated that both $P$. cinnamomi and Phytophthora taxon cranberry were pathogenic at $15^{\circ} \mathrm{C}$; however, Phytophthora taxon cranberry was not pathogenic at $25^{\circ} \mathrm{C}$. The assay used was considered realistic because unrooted cranberry cuttings are commonly used for planting new beds or replanting areas affected by Phytophthora spp. In addition, the vegetative runners often root when they contact bare soil, which again is similar to the assay used in this study. Several Phytophthora species are pathogenic at low temperatures in other plant pathosystems. For example, $P$. fragariae and $P$. megasperma are both low temperature species pathogenic to raspberry (34). It has been reported that in some Phytophthora and Pythium species pathogenicity correlates well with sporangium formation (28). The results obtained in this study support that observation since both sporulation and pathogenicity of Phytophthora taxon cranberry were greatly reduced above $15^{\circ} \mathrm{C}$. Ploetz (28) reported a similar phenomenon with Pythium splendans where vegetative growth was much less sensitive to temperature variation than either sporulation or pathogenicity. Both P. cinnamomi and Phytophthora taxon cranberry reduced plant growth but did not kill plants at high frequencies. In fact, only $50 \%$ of the cuttings inoculated were killed at $15^{\circ} \mathrm{C}$ and there were no significant reductions in the survival of cuttings at $25^{\circ} \mathrm{C}$ compared with the control for either species. This is somewhat typical for Phytophthora species unless plants are subjected to periods of prolonged flooding or other predisposing factors (25).

Perhaps the most interesting similarity of the Phytophthora taxon cranberry isolates with related clade 6 isolates is their affinity for riparian habitats. The zoospores are likely carried in stream water and are introduced into the cranberry system via irrigation water and with cranberry being an incidental host. The cranberry isolates were restricted to only two separate watersheds in the cranberry growing region of New Jersey. This limited distribution suggests either a relatively recent introduction or an effect of the upstream habitat. Since our initial study (24), the distribution of Phytophthora taxon cranberry has not changed.

Metalaxyl is a commonly used fungicide for protecting plants from infection by Phytophthora species (3). Phosphorous acid has been shown to be the active component of the commercial fungicide fosetyl-Al $(12,13)$. The $\mathrm{EC}_{50}$ values found in this study for $P$. cinnamomi correlate well with published values $(6,7)$. Phytophthora taxon cranberry exhibited much higher $\mathrm{EC}_{50}$ values for metalaxyl. Hunger et al. (18) reported that certain isolates of the related species, $P$. megasperma, were naturally tolerant to metalaxyl. Although the origin of the isolates was from commercial cranberry beds that utilized metalaxyl on a regular basis, some of the isolates came from irrigation water upstream of the cranberry acreage. Although, it is outside the scope of this study to determine the biochemical nature of metalaxyl resistance in Phytophthora taxon cranberry, we conclude that metalaxyl and related compounds are inappropriate for use against this species. Phosphorous acid was more active against Phytophthora taxon cranberry and may have good activity in the field. Field tests must be conducted to assess its activity against this species.

In this study, two species of Phytophthora were compared using three criteria. $P$. cinnamomi has been a significant problem across most North American cranberry production areas (with the exception of Wisconsin) and management methods have been developed. We demonstrated that the two species described here are very different in their biology, disease cycles, and ITS sequence similarity. This study confirms earlier findings (24) that major differences in the temperature relations exist between these two species and that type and timing of fungicide applications

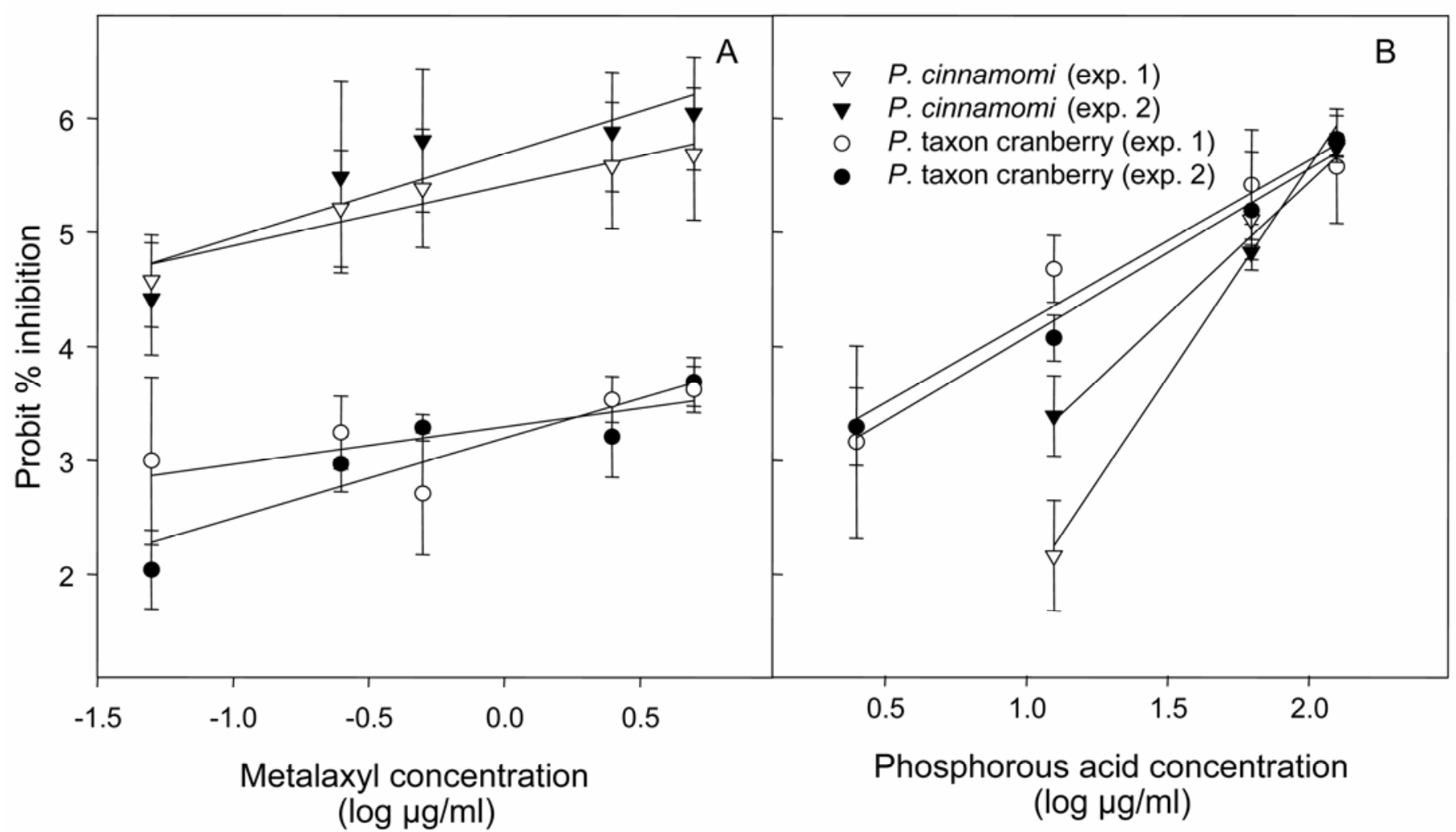

Fig. 4. Effect of fungicide concentrations (A, metalaxyl; and B, buffered phosphorous acid) on radial growth of two Phytophthora species $(P$. cinnamomi $[n=6]$; Phytophthora taxon cranberry $[n=8])$. 


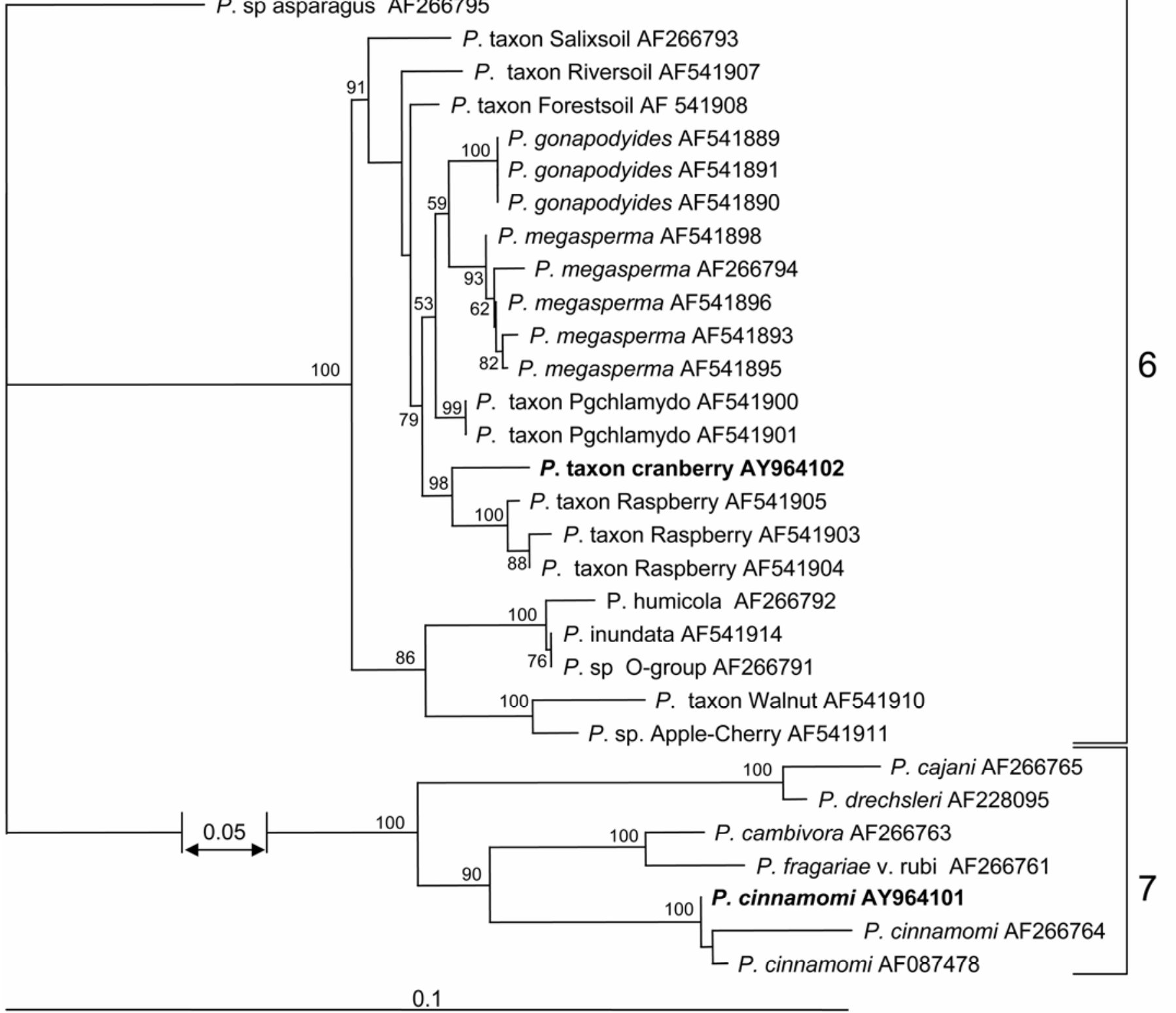

Fig. 5. Phylogram with bootstrap values of representatives of the genus Phytophthora. Bootstrap values below 50 are not displayed. Isolates marked in bold are from this study. The bar represents the number of nucleotide substitutions per site.

will differ depending on the species being treated. Therefore, correct diagnosis of the Phytophthora species present is necessary before implementing a Phytophthora management program.

\section{ACKNOWLEDGMENTS}

Grants from Ocean Spray Cranberries, Inc., and the USDA-CSREES provided funding for the research. We thank G. Crawford for excellent technical assistance, J. A. Crouch for assistance with phylogenetic analyses, and A. B. Howell and J. Johnson-Cicalese for reviewing the manuscript.

\section{LITERATURE CITED}

1. Altschul, S. F., Madden, T. L., Schäffer, A. A., Zhang, J., Zhang, Z., Miller, W., and Lipman, D. J. 1997. Gapped BLAST and PSI-BLAST: A new generation of protein database search programs. Nucleic Acids Res. 25:3389-3402.
2. Brasier, C. M., Cooke, D. E. L., Duncan, J. M., and Hansen, E. M. 2003. Multiple new phenotypic taxa from trees and riparian ecosystems in Phytophthora gonapodyides-P. megasperma ITS clade 6, which tend to be high-temperature tolerant and either inbreeding or sterile. Mycol. Res. 107:277-290.

3. Bruin, G. C. A., and Edgington, L. V. 1983. The chemical control of diseases caused by zoosporic fungi: A many-sided problem. Pages 193232 in: Zoosporic Plant Pathogens. S. T. Buczacki, ed. Academic Press, London.

4. Caruso, F. L., and Wilcox, W. F. 1990. Phytophthora cinnamomi as a cause of root rot and dieback of cranberry in Massachusetts. Plant Dis. 74:664-667.

5. Chen, D.-W., and Zentmyer, G. A. 1970. Production of sporangia by Phytophthora cinnamomi in axenic culture. Mycologia 62:397-402.

6. Coffey, M. D., and Bower, L. A. 1984. In vitro variability among isolates of six Phytophthora species in response to metalaxyl. Phytopathology 74:502-506.

7. Coffey, M. D., and Bower, L. A. 1984. In vitro variability among isolates of eight species of Phytophthora in response to phosphorous acid. Phytopathology 74:738-742. 
8. Cooke, D. E. L., Drenth, A., Duncan, J. M., Wagels, G., and Brasier, C. M. 2000. A molecular phylogeny of Phytophthora and related Oomycetes. Fungal Genet. Biol. 30:17-32.

9. Coyier, D. L., and Roane, M. K. 1986. Compendium of Rhododendron and Azalea Diseases. The American Phytopathological Society, St. Paul, MN.

10. Drilias, M. J., and Jeffers, S. N. 1990. Detection of Phytophthora species in cranberry field soils. Phytopathology 80:1025.

11. Erwin, D. C., and Ribero, O. K. 1996. Phytophthora Diseases Worldwide. The American Phytopathological Society, St. Paul, MN.

12. Fenn, M. E., and Coffey, M. D. 1984. Studies on the in vitro and in vivo antifungal activity of fosetyl-Al and phosphorous acid. Phytopathology 74:606-611.

13. Fenn, M. E., and Coffey, M. D. 1985. Further evidence for the direct mode of action of fosetyl-al and phosphorous acid. Phytopathology 75:1064-1068.

14. Forster, H., and Coffey, M. D. 1993. Molecular taxonomy of Phytophthora megasperma based on mitochondrial and nuclear DNA polymorphisms. Mycol. Res. 97:1101-1112.

15. Greslebin, A. G., Hansen, E. M., Winton, L. M., and Rajchenberg, M. 2005. Phytophthora species from declining Austrocedrus chilensis forests in Patagonia, Argentina. Mycologia 97:218-228.

16. Hansen, E. M., Brasier, C. M., Shaw, D. S., and Hamm, P. B. 1986. The taxonomic structure of Phytophthora megasperma: Evidence for emerging biological species groups. Trans. Br. Mycol. Soc. 87:557-573.

17. Hansen, E. M., Reeser, P. W., Davidson, J. M., Garbelotto, M., Ivors, K., Douhan, L., and Rizzo, D. M. 2003. Phytophthora nemorosa, A new species causing cankers and leaf blight of forest trees in California and Oregon, USA. Mycotaxon 88:129-138.

18. Hunger, R. M., Hamm, P. B., Horner, C. E., and Hansen, E. M. 1982. Tolerance of Phytophthora megasperma to metalaxyl. Plant Dis. 66:645649.

19. Jeffers, S. N. 1988. Phytophthora species associated with a cranberry decline syndrome in Wisconsin. Phytopathology 78:1572.

20. Jeffers, S. N., and Caruso, F. L. 1995. Phytophthora root and runner rot. Pages 28-29 in: Compendium of Blueberry and Cranberry Diseases. F. L. Caruso and D. Ramsdell, eds. The American Phytopathological Society, St. Paul, MN.
21. Kannwischer, M. E., and Mitchell, D. J. 1981. Relationships of numbers of spores of Phytophthora parasitica var. nicotianae to infection and mortality of tobacco. Phytopathology 71:69-73.

22. Miller, P. M. 1955. V-8 juice agar as a general purpose medium for fungi and bacteria. Phytopathology 45:461-462.

23. Mircetich, S. M., and Matheron, M. E. 1976. Phytophthora root and crown rot of cherry trees. Phytopathology 66:549-558.

24. Oudemans, P. V. 1999. Phytophthora species associated with cranberry root rot and surface irrigation water in New Jersey. Plant Dis. 83:251-258.

25. Oudemans, P. V., and Coffey, M. D. 1991. Isozyme comparison within and among worldwide sources of three morphologically distinct species of Phytophthora. Mycol. Res. 95:19-30.

26. Oudemans, P. V., and Coffey, M. D. 1991. A revised systematics of twelve papillate Phytophthora species based on isozyme analysis. Mycol. Res. 95:1025-1046.

27. Page, R. D. M. 1996. TREEVIEW: An application to display phylogenetic trees on personal computers. Comp. Appl. Biosci. 12:357-358.

28. Ploetz, R. C. 2004. Influence of temperature on Pythium splendensinduced root disease on carambola, Averrhoa carambola. Mycopathologia $157: 225-231$.

29. Ribero, O. K. 1978. A Source Book of the Genus Phytophthora. Cramer, Vaduz, Liechtenstein.

30. Stewart, C. N., and Via, L. E. 1993. A rapid CTAB DNA isolation technique useful for RAPD fingerprinting and other PCR applications. BioTechniques 5:748-750.

31. Swofford, D. L. 2002. PAUP. Phylogenetic analysis using parsimony. Sinauer Associates, Sunderland, MA.

32. Tsao, P. H., and Ocana, G. 1969. Selective isolation of species of Phytophthora from natural soils on an improved antibiotic medium. Nature 223:636-638.

33. White, T. J., Bruns, T., Lee, S., and Taylor, J. W. 1990. Amplification and direct sequencing of fungal ribosomal RNA genes for phylogenetics. Pages 315-322 in: PCR Protocols. M. A. Innis, D. H. Gelfand, J. J. Sninsky, and T. J. White, eds. Academic Press, New York.

34. Wilcox, W. F. 1989. Identity, virulence, and isolation frequency of seven Phytophthora spp. causing root rot of raspberry in New York. Phytopathology 79:93-101. 